\title{
The Composition of Normal and Elongated Mycobacterium lepraemurium
}

\author{
By P. DRAPER AND P. D'ARCY HART \\ National Institute for Medical Research, Mill Hill, London, N.W. 7
}

(Accepted for publication 4 December 1967)

\begin{abstract}
SUMMARY
A process is described for preparing suspensions of Mycobacterium lepraemurium from livers of infected mice, free from traces of host tissue. The organisms doubled in length when incubated in 'elongation medium' for I 2-I4 days but did not multiply. Analyses of normal and elongated organisms were made for lipid, phosphorus, nucleic acids, hexosamines, neutral sugars and $\alpha$-amino nitrogen. A doubling of dry weight occurred during elongation, and there was a net synthesis of each of the components measured. Lipid and neutral sugar more than doubled, phosphorus, nitrogen and total nucleic acid rather less than doubled and hexosamine and DNA increased by about one third.
\end{abstract}

\section{INTRODUCTION}

The development of elongated forms by various bacteria grown in adverse con. ditions is a familiar phenomenon. When Hart \& Valentine (1960, 1963) found that Mycobacterium lepraemurium, an organism previously uncultivated in vitro, would elongate in a simple medium, it seemed possible that some small modification of the medium might allow multiplication of the organism. Ultraviolet and electron microscopy seemed to confirm the vital nature of the elongation process (Hart, 1965), and the increase in length was accompanied by a proportional increase in weight, as measured by electron scattering (Valentine, 1962). On the other hand, measurement of protein, nucleic acids and muramic acid in the bacteria suggested that none of these constituents was synthesized during elongation (Hart, 1965). This paper describes an attempt to resolve this paradox by a more detailed analysis of larger quantities of the organism.

\section{METHODS}

Suspension of organisms. Mycobacterium lepraemurium, strain DOUGLAS, was obtained aseptically from experimentally infected mice (Parkes albino strain). A crude suspension of bacteria in bovine serum albumin $(0 . \mathrm{I} \%$ in $0.9 \% \mathrm{NaCl})$ from the homogenized livers of two mice was digested at $37^{\circ}$ with Pronase $(40 \mu \mathrm{g} . / \mathrm{ml}$.) in

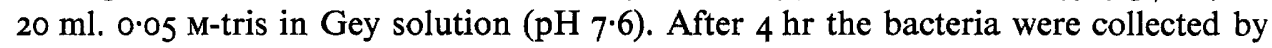
centrifugation, suspended in tris $\mathrm{HCl}$ buffer $(0 . \mathrm{I} \mathrm{M}, \mathrm{pH} 7.2)$ and applied to sucrose density gradients. The gradients consisted of $5 \mathrm{ml}$. of $\mathrm{I} 3.5 \%(\mathrm{w} / \mathrm{v})$ sucrose in $\mathrm{O} \cdot \mathrm{I} \mathrm{M}$-tris buffer $(\mathrm{pH} 7 \cdot 2)$ layered on $5 \mathrm{ml}$. of $50 \%(\mathrm{w} / \mathrm{v})$ sucrose in the same buffer, and allowed to stand for $\mathrm{I} 2-20 \mathrm{hr}$ before use. The gradients were centrifuged at $1000 \mathrm{~g}$ for $\mathrm{I} \mathrm{hr}$, the bands of bacteria removed through the side of the tubes (cellulose nitrate) into sterile syringes, and the bacteria washed and suspended in a measured small volume of $0.1 \%$ albumin in $0.9 \% \mathrm{NaCl}$. About $2 \times 10^{12}$ bacteria were usually obtained 
(about $20 \mathrm{mg}$.). Suspensions for analysis were washed several times in $0.1 \mathrm{M}$-tris $\mathbf{H C l}$ (pH 7.2) containing $0.05 \%$ Tween 80 , then in $0.05 \%$ Tween 80 and finally suspended in water.

Elongation of organisms. Volumes containing $2 \times 10^{11}$ organisms of purified Mycobacterium lepraemurium, determined by direct counts of dilutions of the suspensions (Hart \& Rees, 1960), were inoculated into $200 \mathrm{ml}$. of 'elongation medium' at pH 6.4 (Hart \& Valentine, 1963), containing benzylpenicillin $0.24 \mathrm{mg} . / \mathrm{ml}$. in Thompson bottles. The bottles were incubated undisturbed at $37^{\circ}$ for $12-14$ days. Bacterial contamination of the suspensions was excluded before and after elongation by examining smears stained by the Ziehl-Neelsen method, and by inoculating samples into Headley-Wright broth. For analysis the elongated bacteria were collected and washed in the same way as the normal ones. Suspensions were usually counted to check recoveries.

Analysis of bacterial constituents. To avoid transferring very small amounts of dry material, analyses were performed on measured volumes of suspensions with known dry weights and (in most batches) known bacterial populations. For dry weights bacteria were dried for $16 \mathrm{hr}$ at $80^{\circ}$ in weighed glass vials. Populations were determined by direct counting of stained suspensions of bacteria (Hart \& Rees, 1960). Amounts of bacterial constituents were calculated as $\%$ of the dry weight of organisms.

Size of organisms. Lengths of bacteria were measured with the electron microscope.

Lipids. Dried material was repeatedly extracted at room temperature with chloroform + methanol $(2+\mathrm{I}$ by vol., $4 \times \mathrm{I} \mathrm{ml} ., 24 \mathrm{hr}$ each extraction). The residual material was dried at $80^{\circ}$ and reweighed.

Phosphorus. Samples were ashed and phosphorus contents measured by the method of Chen, Toribara \& Warner (1956). 'Non-lipid phosphorus' was measured in the insoluble residue after extraction with chloroform + methanol (see above), and nucleic acid phosphorus in ashed nucleic acid extracts (see below).

$\alpha$-Amino nitrogen. Samples were hydrolysed in $4 \mathrm{~N}-\mathrm{HCl}$ for $\mathrm{I} 6 \mathrm{hr}$ at $105^{\circ} . \alpha$-Amino nitrogen in the hydrolysates was measured with ninhydrin (Rosen, 1957), with DL-alanine as standard.

Nucleic acids. Nucleic acids were extracted from bacterial samples with two or three portions of $5 \%$ trichloroacetic acid at $90^{\circ}$ for $10 \mathrm{~min}$. The DNA in these extracts was measured with diphenylamine (Burton, 1956), with deoxyribose as a standard, and RNA with orcinol (Schneider, 1957) using ribose as a standard. Total nucleic acids were determined spectrophotometrically. Bacterial samples were extracted successively as follows, supernatant extracts being discarded in each case: $0.2 \mathrm{~N}^{-} \mathrm{HClO}_{4}$ for Io min. at $0^{\circ} ; 75 \%$ (v/v) aqueous ethanol (buffered with $0.1 \mathrm{M}$-ammonium acetate) for $15 \mathrm{~min}$. at $37^{\circ}$; buffered ethanol + ether $(\mathrm{I}+\mathrm{I}, \mathrm{v} / \mathrm{v})$ for $15 \mathrm{~min}$. at $37^{\circ}$. After this preliminary treatment nucleic acids were extracted from bacterial samples with trichloroacetic acid (as above), the solutions were made $0 . \mathrm{I} \mathrm{N}$ in $\mathrm{HClO}_{4}$ and the trichloroacetic acid was removed by ether extraction. Nucleic acids were determined from the extinction at $260 \mathrm{~m} \mu$ of these solutions, with sodium ribonucleate from yeast as a standard. Contamination with protein was detected as extinction at $232 \mathrm{~m} \mu$ (Munro \& Fleck, I966).

Hexosamines. Samples were hydrolysed in $4 \mathrm{~N}-\mathrm{HCl}$ for $4 \mathrm{hr}$ at $105^{\circ}$. Hexosamines were measured by the method of Blix (1948), with glucosamine hydrochloride as a standard. To test for possible interference by other substances in the hydrolysate 
individual hexosamines were determined in a hydrolysate from a large batch of normal Mycobacterium lepraemurium, by using the modification by Crumpton (1959) of the ion-exchange separation of Gardell (1953).

Neutral sugars. Samples were hydrolysed in $2 \mathrm{~N}^{-} \mathrm{H}_{2} \mathrm{SO}_{4}$ for $3 \mathrm{hr}$ at $105^{\circ}$. Total reducing sugars in the hydrolysed samples were measured by the phenol + sulphuric acid method (Dubois et al. 1956), with glucose and galactose as standards. Individual components were identified by thin-layer chromatography on cellulose (Vomhof \& Tucker, 1965). The plates, dried at $35^{\circ}$ and ambient humidity, effected satisfactory separations of sugars with the solvent advocated, formic acid + butan-2-one + tertbutanol + water ( $15+30+40+15$ by vol.; Fink, Cline $\&$ Fink, 1963) as well as with ethyl acetate + pyridine + water $(2+\mathrm{I}+2$, by vol.; Jermyn \& Isherwood, 1949) and $n$-butanol + acetic acid + water ( $4+\mathrm{I}+\mathrm{I}$, by vol.).

Sugars were detected with alkaline silver nitrate (Trevelyan, Procter \& Harrison, I950), aniline phthalate (Partridge, 1949) or periodate + benzidine (Cifonelli \& Smith, 1954).

Amounts of various components were estimated by gas-liquid chromatography of trimethylsilyl ethers of the sugars, kindly done by Mr N. Gregory. Amounts of glucose in hydrolysates were measured with glucose oxidase (Bergmeyer \& Bernt, I963).

Chemicals. Sodium ribonucleate from yeast was supplied by British Drug Houses Ltd., glucose oxidase was from Koch-Light Ltd., Pronase from Calbiochem and MN-cellulose powder $300 \mathrm{G}$ from Macherey, Nagel and Co.

\section{RESULTS}

Length and weight of organisms. The mean weight of normal Mycobacterium lepraemurium was $\mathrm{I} \cdot 33 \pm 0.23$ S.D. $\times 10^{-14} \mathrm{~g}$. ( 5 batches), and of elongated bacteria $2 \cdot 65 \pm 0 \cdot 6 \mathrm{I} \mathrm{S.D.} \times 10^{-14} \mathrm{~g}$. (7 batches). The bacterial weights obtained directly and the bacterial lengths measured electron microscopically in a single experiment are compared in Table I. Electron microscopy, according to the methods of Valentine (1962), also showed that the densities of normal and elongated bacteria were similar, so that weight increased proportionally to length.

Table I. Weights and lengths of Mycobacterium lepraemurium

$\begin{array}{lcc} & \begin{array}{c}\text { Dry wt per } \\ \text { organism }(\mathrm{g} .)\end{array} & \text { Length }(\mu) \\ \text { Normal } & 1 \cdot 7 \times 10^{-14} & 1 \cdot 62(\text { range } I \cdot 0-2 \cdot 6) \\ \text { Elongated } & 2.8 \times 10^{-14} & 3.08(\text { range } 1 \cdot 2-5 \cdot 6) \\ \text { Relative increase } & 1.65 & 1 \cdot 9\end{array}$

Dry weights were measured by drying known numbers of bacteria at $80^{\circ}$ for $16 \mathrm{hr}$. Lengths were measured directly with an electron microscope. The results are for a single batch of bacteria.

Lipids. The lipid content of bacteria was large, and in the elongated bacteria variable. Material amounting to $27.5 \pm 2.5$ S.D. $\%$ (4 batches) of the dry weight of normal bacteria and $32 \pm 6 \cdot 2$ S.D. $\%$ ( 7 batches) of elongated bacteria was soluble in chloroform + methanol.

Phosphorus. Normal bacteria contained $\mathrm{I} \cdot 3 \%$ (3 batches) of phosphorus, elongated bacteria $\mathrm{I} \cdot 15 \pm 0.06$ s.D. $\%$ ( 6 batches). Chloroform + methanol extraction removed $0.26 \%$ (I batch; $20 \%$ of the total phosphorus) from normal bacteria and $0.27 \pm 0.02$ 
S.D. $\%$ ( 3 batches; $23 \%$ of the total phosphorus) from elongated bacteria. Trichloroacetic acid extracts from normal bacteria contained phosphorus corresponding to $\mathrm{I} \cdot \mathrm{I} \%$ ( 2 batches) of the dry weight of the organisms, from elongated bacteria to $0.9 \%$ ( 4 batches). These amounts correspond to II and $9 \%$ nucleic acid, respectively (calculated as RNA).

Nucleic acids. Normal bacteria contained $4 \cdot 9 \pm 0.3$ S.D. $\%$ (3 batches) and elongated bacteria $4 \cdot 1 \pm 0.9$ S.D. $\%$ ( 5 batches) of total nucleic acids, measured spectrophotometrically. Normal bacteria contained $0.74 \pm 0.05$ S.D. $\%$ (4 samples) of deoxyribose, corresponding to $3.4 \%$ DNA and, by difference from the total nucleic acid, $\mathrm{I} \cdot 5 \%$ RNA. Elongated bacteria contained $0.44 \pm 0.10$ S.D. $\%$ ( 9 batches) of deoxyribose, corresponding to $2.0 \%$ DNA and $2.1 \%$ RNA by difference. The calculated amounts of DNA assume that it contains $22 \%$ deoxyribose, which is correct only for DNA containing equal numbers of purine and pyrimidine bases.

Ribose, measured by the orcinol reaction, was apparently present in bacteria as follows: normal 8.0 \pm 0.05 S.D. $\%$ (4 batches), elongated $6.3 \pm 0.5$ S.D. $\%$ ( 8 batches). These values correspond to 35 and $27 \%$ of RNA, respectively, assuming RNA contains $23 \%$ ribose. The orcinol reaction is not very specific, and it is probable that other carbohydrate (see below) was extracted from the bacilli together with the nucleic acids and contributed to the colour obtained in the orcinol reaction.

$\alpha$-Amino nitrogen. Normal bacteria contained $5.0 \%$ of nitrogen ( 2 batches), elongated bacteria $4 \cdot 1 \%$ ( 2 batches), measured as alanine.

Table 2. Amounts of neutral sugars in Mycobacterium lepraemurium, relative to arabinose, measured by gas-liquid chromatography

$\begin{array}{lcc}\begin{array}{c}\text { Normal } \\ \text { bacteria }\end{array} & \begin{array}{c}\text { Elongated } \\ \text { bacteria }\end{array} \\ \text { Arabinose } & \mathrm{I} \cdot 0 & \mathrm{I} \cdot 0 \\ \text { Galactose } & 0.6 & 0.5 \\ \text { Glucose } & \mathrm{I} \cdot 8 & 0.5 \\ \text { Inositol } & 0.3 & 0.1 \\ \text { Mannose } & 0.8 & 0.6\end{array}$

Table 3. Amounts of various substances in normal and elongated Mycobacterium lepraemurium

\begin{tabular}{lccc} 
& \multicolumn{3}{c}{ Weight (units of IO $^{-14} \mathbf{g}$. per organism) } \\
\cline { 2 - 4 } & Normal & Elongated & Increase \\
Whole bacillus (dry wt) & 1.33 & 2.65 & 2.0 \\
Lipid & 0.36 & 0.86 & 2.4 \\
Phosphorus & 0.017 & 0.030 & 1.8 \\
Total nucleic acid & 0.065 & 0.11 & 1.7 \\
Deoxyribose & 0.01 & 0.013 & 1.3 \\
a-Amino nitrogen & 0.066 & 0.11 & 1.6 \\
Hexosamine & 0.028 & 0.037 & 1.3 \\
Neutral sugar & 0.20 & 0.52 & 2.6 \\
Ribose & 0.11 & 0.17 & 1.5
\end{tabular}

Hexosamines. Total hexosamines in normal bacteria were $2 \cdot 1 \%$ ( 2 batches) and in elongated bacteria $\mathrm{I} .4 \%$ ( 3 batches). Further analysis of one sample indicated that normal bacteria contained $0.82 \%$ of glucosamine, $0.71 \%$ of muramic acid, $0.49 \%$ 
of an unknown material eluted from the column more slowly than other components and $0.32 \%$ of galactosamine.

Neutral sugars. Total neutral sugars were as follows: normal bacteria $14 \cdot 8 \pm \mathrm{I} \cdot 3 \mathrm{~S}$ S.D. $\%$ (3 batches), elongated bacteria $19 \cdot 6 \pm 3 \cdot 4$ S.D. $\%$ ( 4 batches), as galactose. Glucose oxidase detected $4.8 \%$ of glucose in normal and $4.4 \%$ in elongated bacteria (I batch each). Thin-layer and gas-liquid chromatography showed the following sugars to be present: glucose, galactose, arabinose, mannose and inositol. A fast-running spot was observed on thin-layer chromatograms, possibly a deoxyhexose, and small amounts of at least three unidentified components were detected by gas-liquid chromatography. The amounts of the various components relative to arabinose are shown in Table 2. No ribose or ribitol could be detected.

Summary of analyses. The amounts of the various bacterial components expressed in g. dry wt per organism, and the relative increases associated with elongation are summarized in Table 3.

\section{DISCUSSION}

At each stage of investigation of the elongation of Mycobacterium lepraemurium the question has arisen whether the process could be considered as near-multiplication, so offering a hopeful lead in attempts to cultivate the organism (and possibly $M$. leprae), or whether it was a passive swelling process, and of interest only as a means of identifying the organism. Earlier analyses by Drs J. Mandelstam and A. J. Garrett (reported by Hart, 1965) were hampered by very small numbers of bacteria available, and by contamination of the suspension with material from the liver of the host. About Ioo times more bacteria were available for the present experiments, and the treatment with Pronase and density-gradient separation removed all host material as judged immunologically by the Ouchterlony technique.

Although the observed percentages of bacterial components depend only on measured weights, the calculated increases in bacterial weights and amounts of components depend on the recovery of the original inoculum. Counting of suspensions of elongated bacteria indicated recoveries of between 50 and $100 \%$, but the results were uncertain because some 'clumping' of bacteria occurred. Attempts to separate the bacteria by ultrasonic treatment led to lower counts, presumably because the bacteria were fragile. Recovery was therefore assumed to be complete in each case, and consequently it is possible that increases in bacterial dry weights and amounts of individual components were actually somewhat greater than reported.

If a normal cell of Mycobacterium lepraemurium is taken to be a cylindrical rod $\mathrm{I} \cdot 5 \mu$ long and $0.13 \mu$ in radius, its volume is $8 . \mathrm{I} \times 1 \mathrm{IO}^{-14} \mathrm{ml}$. Undried Mycobacterium tuberculosis contains $86 \%$ of water, and has a density $\mathrm{I} \cdot \mathrm{I} \mathrm{g} . / \mathrm{ml}$. (Luria, I960). Assuming a similar water content for undried $M$. lepraemurium, a density of $\mathrm{I} \cdot \mathrm{I}-$ $\mathbf{I} \cdot \mathbf{2} \mathrm{g} . / \mathrm{ml}$., confirmed by its behaviour in the sucrose density gradients, and a volume of $8 \cdot \mathrm{I} \times 10^{-14} \mathrm{ml}$., its wet weight should be $8 \cdot 9-9 \cdot 7 \times 10^{-14} \mathrm{~g}$., and its dry weight $\mathrm{I} \cdot 25-\mathrm{I} \cdot 36 \times 10^{-14} \mathrm{~g}$., a value which agrees well with the dry weight of normal bacteria measured here. Direct weighing of bacteria confirmed the evidence obtained with the electron microscope that an increase of bacterial weight occurred during elongation.

Each of the components measured increased in total amount in the elongated bacteria. Only small increases of DNA and hexosamines were found. A failure to synthesize sufficient new DNA might explain the failure of the bacteria to divide. 
Hexosamines occur especially in the cell-wall mucopeptide, and provide a measure of the increase of the 'backbone' of the cell wall.

Increases rather less than proportional to the weight increase occurred in phosphorus, total nucleic acids (measured by u.v. absorption) and $\alpha$-amino nitrogen (mainly derived from protein). RNA measured by the orcinol reaction also increased but was grossly interfered with by other material extracted by trichloroacetic acid, probably carbohydrate. An attempt to extract RNA selectively by the SchmidtThannhauser process (Munro \& Fleck, 1966), which uses dilute alkali, did not yield any ultraviolet absorbing material. The RNA content calculated by subtracting DNA from total nucleic acids also increased. Although the possibility that there was some ultraviolet absorbing non-nucleic acid material in the extracts prevents great reliance being placed on this increase, it appears that more new RNA is synthesized than DNA by the elongated bacteria. The ratio $E_{232} / E_{260}$ was greater for bacterial nucleic acid extract than for pure RNA, indicating that some protein was present. The extracts also contained more phosphorus than could be accounted for as nucleic acid.

Lipid increased on average more than proportionally to the weight, as did carbohydrate, but there were large variations in lipid content and increase in different batches. Agreement between duplicate samples of each batch indicated that the variations were not primarily due to loss of material in extraction. In one experiment a decrease in percentage (though not of absolute amount) occurred. Carbohydrate increased regularly, though different batches had differing initial contents. Of the various components mannose and inositol are probably derived from a phospholipid similar to that studied in Mycobacterium phlei by Lee \& Ballou (I965), glucose may form a bacterial glycogen such as that described by Chargaff \& Moore (I944) in $M$. tuberculosis, and galactose and arabinose may occur in an arabinogalactan such as that found by Misaki \& Yukawa (1966) in M. tuberculosis strain BCG. Mr M. R. Young (see Hart, 1965 ) described an increase in numbers and size of bacterial granules which absorbed at $257 \mathrm{~m} \mu$ and could be stained (in elongated bacteria only) by euchrysin, a dye which stains DNA. Since DNA and phosphate did not increase excessively in the bacteria, the suggested identification of the granules as DNA or as polyphosphate carrying DNA seems unlikely. It is more likely that they are of lipid or carbohydrate, possibly carrying absorbed DNA. The presence of DNA on or in the granules would suggest some disorganization of the elongated bacteria. Schaefer \& Lewis (1965) showed lipid granules in Mycobacterium kansasii.

Kátó \& Gözsy (1966) described a medium, rather different from elongation medium in which a limited multiplication of Mycobacterium lepraemurium occurred, with an optimal $\mathrm{pH} 8.5$ (our elongation medium is at $\mathrm{pH} 6 \cdot 0-6 \cdot 5$ ) and containing $2 \%$ of sodium chloride and a plant polysaccharide, gum guar. Multiplication could be maintained in the medium for six generations of bacteria. It is not clear what relation elongation at acid pH has to multiplication in Kátó's alkaline-galactomannan medium or what relation either has to multiplication of the bacteria in vivo. Neither elongation nor multiplication occurs in elongation medium at alkaline $\mathrm{pH}$.

The conclusion of Hart (1965) that elongation was a 'low-grade form of living growth in vitro' has been confirmed by analysis; Mycobacterium lepraemurium was apparently able to synthesize at least a little of all the macromolecular substances needed for growth. It remains to be investigated which components of the medium provide the raw materials. 
We are grateful to Dr R. C. Valentine for examining the mycobacteria with the electron microscope and to $\mathrm{Dr}$ R. J. W. Rees for providing suspensions of $M y c o-$ bacterium lepraemurium, and for making bacterial counts.

\section{REFERENCES}

BERGMEYER, H.-U. \& BERNT, E. (1963). D-Glucose : determination with glucose oxidase and peroxidase. In Methods of Enzymatic Analysis. Ed. by H.-U. BerGMEYER. p. I23. Weinheim: Verlag Chemie GMBH.

BLIx, G. (I948). The determination of hexosamines according to Elson and Morgan. Acta chem. scand. 2, 467 .

Burton, K. (1956). A study of the conditions and mechanism of the diphenylamine reaction for the colorimetric estimation of deoxyribonucleic acid. Biochem. J. 62, 315.

Chargaff, E. \& Moore, D. H. (1944). On bacterial glycogen: the isolation from avian tubercle bacilli of a polyglucosan of very high molecular weight. J. biol. Chèm. 155, 493.

Chin, P.S., Toribara, T. Y. \& Warner, H. (1956). Microdetermination of phosphorus. Analyt. Chem. 28, 1756.

Cifonelli, J. A. \& SMith, F. (1954). Detection of glycosides and other carbohydrate compounds on paper chromatograms. Analyt. Chem. 26, I 132.

Crumpton, M. J. (1959). Identification of amino-sugars. Biochem. J. 72, 479.

Dubois, M., Gilles, K. A., Hamiton, J. K., Rebers, P. A. \& Smith, F. (1956). Colorimetric method for determination of sugars and related substances. Analyt. Chem. 28, 350.

Fink, K., Cline, R. E. \& FinK, R. M. (I963). Paper chromatography of several classes of compounds: correlated $R_{F}$ values in a variety of solvent systems. Analyt. Chem. 35, 389.

GARDELL, S. (1953). Separation on Dowex 50 ion exchange resin of glucosamine and galactosamine and their quantitative determination. Acta chem. scand. 7, 207.

HART, P. D'ARCY (1965). Further analysis of the growth (elongation) phenomenon of Mycobacterium lepraemurium in vitro, and relevant studies with Mycobacterium leprae. Int. J. Lepr. 33, 504.

HART, P. D'ARCY \& REES, R. J. W. (1960). Effect of Macrocyclon in acute and chronic pulmonary tuberculosis infection in mice as shown by viable and total bacterial counts. Br. J. exp. Path. 4I, $4 \mathrm{I} 4$.

HART, P. D'Arcy \& VAlentine, R. C. (1960). Elongation of a leprosy bacillus (Mycobacterium lepraemurium) in a cell-free medium. Nature, Lond. $\mathbf{1 8 5}, 58$.

HART, P. D'Arcy \& VAlentine, R. C. (1963). Growth (without multiplication) of Mycobacterium lepraemurium in cell-free medium. J. gen. Microbiol. 32, 43.

JERMYN, M. A. \& ISHERWOOD, F. A. (1949). Improved separation of sugars on the paper partition chromatogram. Biochem. J. 44, 402.

KÁTó, L. \& GözsY, B. (1966). Limited multiplication of Mycobacterium lepraemurium in parabiotic culture as influenced by osmolarity of an alkaline-galactomannan medium. J. Bact. 9r, 1859.

LeE, Y. C. \& Ballou, C. E. (1965). Complete structures of the glycophospholipids of mycobacteria. Biochemistry 4, 1395.

Luria, S. E. (1960). In The Bacteria. Ed. by I. C. Gunsalus and R. Y. Stanier. Vol. I, p. I3. New York: Academic Press.

Misaki, A. \& YUKaWA, S. (I966). Studies on cell walls of mycobacteria. 2. Constitution of polysaccharides from BCG cell walls. J. Biochem., Tokyo 59, $51 \mathrm{I}$.

MunRo, H. N. \& FleCk, A. (1966). The determination of nucleic acids. Meth. biochem. Analysis 14, II3.

PARTRIDGe, S. M. (1949). Aniline hydrogen phthalate as a spraying reagent for chromatography of sugars. Nature, Lond. 164, 443.

Rosen, H. (1957). A modified ninhydrin colorimetric method for amino acids. Archs. Biochem. Biophys. 67, 10.

Schaefer, W. B. \& Lewis, C. W. (I965). Effect of oleic acid on growth and cell structure of mycobacteria. J. Bact. $90,1438$.

SchneIder, W. C. (1957). Determination of nucleic acids in tissues by pentose analysis. Meth. Enzymol. 3, 680. 
Trevelyan, W. E., Procter, D. P. \& Harrison, J. S. (1950). Detection of sugars on paper chromatograms. Nature, Lond. 166, 444.

VALENTINe, R. C. (1962). Quantitative electron microscopy of leprosy bacilli. Br. med. Bull. 18, 242. VomHof, D. W. \& TUCKeR, T. C. (1965). The separation of simple sugars by cellulose thin-layer chromatography. J. Chromat. 17, 300. 